\begin{tabular}{ll}
\hline Jurnal Scripta Teologi dan Pelayanan Kontekstual & \\
ISSN 2086-5368 (Print) & STT Ebenhaezer \\
ISSN & STTE \\
Http://ejournal.stte.ac.id & \\
Vol.1, No.2, pp. 1-20, 2016 &
\end{tabular}

\title{
Prinsip Filsafat Sebagai Ancilia Theologiae Dan Kontribusinya Bagi Mahasiswa Sekolah Tinggi Theologia
}

Marlon Butar-butar

STT Ebenhaezer Tanjung Enim, marlonbutarbutar1968@gmail.com

\begin{tabular}{l} 
INFO ARTIKEL \\
\hline Sejarah Artikel: \\
Diterima : 03 Nov 2016 \\
Direvisi : 08 Nov 2016 \\
Disetujui: 20 Nov 2016 \\
Dipublikasi: 28 Nov \\
2016
\end{tabular}

Kata Kunci:

keyword one, keyword two, keyword three.

Keywords:

keyword one, keyword two, keyword three.

\begin{abstract}
ABSTRAK
Filsafat lahir sejak manusia mulai berpikir, karenanya perannya sangatlah penting dalam hidup dan kemajuan manusia. Tidak ada penemuan tanpa didahuli proses bertanya dan mencari jawabannya. Di sanalah filsafat memainkan peran. Karena itu manusia modern tidak mungkin meninggalkan filsafa. Filsafat tidak menyelidiki salah satu segi dari kenyataan saja, melainkan apa-apa saja yang menarik perhatian manusia. Komposisi filsafat mengandung pertanyaan mengenai asalusul dan tujuan, tentang hidup dan kematian, tentang hakikat manusia. Sederhananya, berfilsafat adalah kegiatan untuk mencari tahu. Dalam perkembangannya filsafat telah mendominasi ratio manusia untuk menetukan benar salah suatu pemikiran. Perkembangan ini pun sangat dimanfaatkan oleh para ilmuwan, yang akhirnya benar-benar sangat mempengaruhi soal-soal spiritual, termasuk bidang teologia. Dalam sejarah dua bidang ini sangat kuat saling mempengaruhi hingga pada abad pertengahan hingga modern filsafat seolah meninggalkan teologia, akhirnya banyak pihak menjadi antipati terhadapnya, karena dianggap sebagai musuh teologia. Keadaan ini sangat mempengaruhi sikap dan minat belajar mahasiswa di mana penulis berkecimpung, karenanya sebagai satu refleksi tulisan ini dibuat agar dapat mengembalikan peran filsafat dalam teologia.
\end{abstract}

\section{ABSTRACT}

Philosophy was born since humans began to think, therefore its role is very important in human life and progress. There is no discovery without the process of asking questions and finding the answers. That's where philosophy plays a role. Therefore, modern humans can not leave philosophers. Philosophy does not investigate just one aspect of reality, but anything that attracts human attention. The philosophical composition contains questions about the origin and purpose, about life and death, about human nature. Simply put, philosophy is an activity to 
find out. In its development, philosophy has dominated the human ratio to determine whether a thought is correct. This development was greatly utilized by scientists, who ultimately really greatly influenced spiritual matters, including the field of theology. In the history of these two fields very strongly influenced each other until the Middle Ages to modern philosophy as if leaving theology, eventually many parties became antipathy towards it, because it was considered an enemy of theology. This situation greatly affects the attitudes and students' interest in learning where the author is involved, therefore as a reflection this paper is made in order to restore the role of philosophy in theology.

\section{Pendahuluan}

Pada umumnya orang mengklaim bahwa filsafat adalah induk dari semua disiplin ilmu yang ada, sehingga mereka pun mengklaim bahwa philosophy is the queen of sciences. Sebagai queen, dunia (world) secara fisik adalah wilayah kekuasaan filsafat, termasuk dunia non fisik (the universe). ${ }^{1}$ Will Durant menegaskan filsafat mendominasi atas semua disiplin ilmu pengetahuan dengan menyatakan: "Philosophy is still Regina Scientiarum, and would be everywhere recognized as such if she clothed herself in her ancient majestic, brought all the sciences into her service, and took knowledge as her instrument". ${ }^{2}$ Dominasi filsafat sebagai the queen adalah bahwa semua ilmu pengetahuan berada di bawah pelayanannya dan menjadi alatnya. Kemudian ilmu pengetahuan itu dikembangkan dan menjadi bagian-bagian yang tidak berhubungan satu dengan yang lain seperti: fisika, biologi, matematika, geologi, astronomi, logika, retorika, etika dan sebagainya. Namun filsafat dapat menghubungkannya, karena filsafat adalah sistem yang interdisipliner. ${ }^{3}$

Dalam perkembangannya filsafat pun semakin mendominasi hingga merambat pada pemikiran tentang Tuhan (Theos). Mempertanyakan tentang siapa Allah? Apakah Allah itu ada? Terbuat dari zat apa? Apakah argumentasi-argumentasi untuk membuktikan Allah itu sah? Apakah argumen-argumen itu benar? Pertanyaan demikian adalah persoalan yang dapat didekati dari sudut filsafat. ${ }^{4}$ Filsafat dapat menyingkapkan dimensi-dimensi tertentu dalam diri manusia yang mengacu kepada adanya Tuhan dan juga kepada kemungkinan adanya wahyu. ${ }^{5}$ Pada abad Gereja mula-mula, mulailah filsafat dipakai di dalam gereja, pelopornya adalah bapak Gereja Yustinus Martir (meninggal $165 \mathrm{M}$ ), Tertullianus (160-220 M) dan Agustinus (354-430 M) sebagai yang terkemuka pada era ini. ${ }^{6}$ Namun oleh karena sistem filsafat lebih menekankan hal-hal yang logic, maka filsafat lebih berorientasi kepada pemuasan intelektual, yakni: menerima yang rasional dan menolak yang irasional. Tidak ketinggalan juga sikap para filsuf yang mengagung-agungkan sampai pada pendewaan filsafat yang akhirnya mengubah paradigma bertheologia Gereja pada abad pertengahan dengan theologia skolastik dan pada era modern dengan theologia liberal. Pada masa pemakaian filsafat

\footnotetext{
${ }^{1}$ Norman L. Geisler, Paul D. Feinberg, Filsafat..., 24

${ }^{2}$ Will durant, The Pleasures of Philosophy: An Attempt at a Consistent Philosophy of Life, (New York: Simon and Schuster, 1953), 11

${ }^{3}$ Soetrino, Filsafat Ilmu Metodologia Penelitian, (Yogyakarta: ANDI, 2007), 57

${ }^{4}$ Ronald H, Nash, Iman Dan Akal Budi, (Surabaya: Momentum, 2001), 16

${ }^{5}$ Nico Syukur Dister, Filsafat Agama Kristiani, (Yogyakarta: Kanisius, 1985), 11

${ }^{6}$ Colin Brown, Filsafat \& Iman Kristen 1, (Surabaya: Momentum, 2008), 10
} 
dalam theologia Kristen, para filsuf tidak jujur mempropagandakan sisi filsafat dan theologia. Mereka hanya mengklaim bahwa filsafat adalah regina scientiarum atau mother of sciences (induk dari ilmu pengetahuan) tanpa melihat pada hakikat klaim filsafat sebagai ancilla theologiae.

Serangan secara sistematis terhadap theologia mulai bangkit bersamaan dengan bangkitnya filsafat modern. Salah satu filsuf yang dengan intensional dan sistematis menyerang secara langsung theologia Kristen adalah Baruch Spinoza (1632-1677), seorang filsuf rasionalisme berdarah Yahudi.7 Beliau dianggap sebagai atheis karena dikenal sebagai pelopor para pengkritik sumber theologia kristen, yakni Alkitab. ${ }^{8}$ Beliau berpendapat dalam Alkitab ada Firman Allah, tidak semua teks Alkitab adalah Firman Allah, karena baginya Alkitab penuh dengan kontradiksi. ${ }^{9}$ Periode ini juga memunculkan filsafat humanis dan ilmu-ilmu modern yang empiris-rasional menentang pemahaman dan penghayatan iman. ${ }^{10}$ Selain Spinoza, Soren Kierkegarrd (1813-1855) adalah filsuf kontemporer yang dikenal dengan filsafat eksistensialismenya, yang menyerang theologia Kristen dengan sistem berpikirnya yang pantheistik. Dimulai dari upayanya mendefenisikan Allah yang diakuinya tidak dapat dikenal, sampai menolak otensitas Alkitab yang bertolak dari penulis, kesatuan dan inspirasi. Baginya inspirasi Alkitab adalah subyektif. ${ }^{11}$

Kesalahan memahami peranan filsafat yang sesungguhnya dalam theologia Kristen telah mengira bahwa filsafat adalah kombinasi yang membahayakan dan sulit dipahami. Sementara yang lain menganggap filsafat sebagai alat iblis.

Karena kesan yang buruk terhadap filsafat demikian kuat, maka sekolah tinggi teologia tidak mudah menerima adanya mata kuliah filsafat dalam strata satu, sekalipun telah ditetapkan dalam kurikulum inti yang dikeluarkan oleh Direktur Bimbingan Masyarakat Kristen pada kantor kementerian agama RI. Pada hal tidak mungkin mempelajari mata kuliah apologetika, etika, dan theologia kontemporer, tanpa mempelajari terlebih dahulu mata kuliah filsafat. Teolog tidak mungkin menghindari perjumpaan theologianya terhadap filsafat, oleh sebab itu theolog tidak bisa menghindari untuk mempelajari filsafat. Paulus sendiri berfilsafat (he reasoned) dengan para penganut epicureanisme dan stoicisme (Kis. 17:18). ${ }^{12}$

\section{Metode Penelitian}

Di dalam penulisan karya ilmiah ini penulis menggunakan metode deskriptifTheologis. Dikatakan metode deskriptif karena metode penelitian dilakukan dengan cara meneliti status sekelompok manusia, suatu objek, suatu set kondisi, suatu sistem pemikiran ataupun suatu kelas peristiwa pasa masa sekarang. Tujuannya ialah untuk membuat deskripsi, gambaran atau lukisan secara sistematis, faktual dan akurat mengenai fakta-fakta, sifat-sifat serta hubungan antarfenomena yang diselidiki. ${ }^{13}$ Penulis menggunakan paradigma penelitian kualitatif dengan metode deskriptif adalah karena penulis akan menggambarkan dengan mengumpulkan data alamiah yang ada.

\footnotetext{
${ }^{7}$ Stevri Indra Lumintang, Keunikan ..., 171

${ }^{8}$ Colin Brown, Filsafat 1..., 71

${ }^{9}$ Eta Linneman, Theologia Kontemporer: Ilmu atau Praduga? (Batu: Penerbit Institut Injil Indonesia, 1991), 33

${ }^{10}$ A. Sudiarja, Filsafat dan Teologi, (Malang: SAAT, 2002), 13

${ }^{11}$ Eta Linneman, Theologia Kontemporer..., 57-58

${ }^{12}$ Ibid., 180

${ }^{13}$ Moh. Nazir, Metode Penelitian, (Jakarta: Ghalia Indonesia, 1988), 63
} 
Menurut Koentjaraningrat, dikatakan deskriptif karena menjelaskan permasalahan secara sistematis dan faktual mengenai fakta-fakta yang terjadi. ${ }^{14}$ Dikatakan Theologis karena data yang dikumpulkan dalam penelitian ini adalah penelitian untuk memberikan pemahaman yang benar secara theologi. Penekanan utamanya ialah pada bagaimana iman Kristen dapat mengubah sifat kehidupan dan situasi manusia, dan pengubahan tersebut harus didahului oleh pemahaman yang benar akan Alkitab. ${ }^{15}$

\section{Hasil Dan Pembahasan}

\section{Problematika Mahasiswa Terhadap Studi Filsafat}

Pada bagian ini penulis akan menguraikan sejumlah problematika mahasiswa STT perihal studi filsafat.

\section{Praduga yang keliru}

Kebanyakan mahasiswa telah menuduh filsafat bersalah tanpa bukti, praduga yang keliru menjadi asas berpikir negatif mahasiswa dengan studi filsafat dan praduga yang keliru. Dugaan yang keliru terhadap studi filsafat otomatis menstimulasi mahasiswa pada sikap fobia filsafat.

\section{Belum pernah belajar filsafat}

Sebenarnya fobia sebagian besar mahasiswa terhadap studi filsafat, perlu diklarifikasi kembali, karena banyak orang yang tertarik dengan studi filsafat namun lantaran penyajian filsafat di kursi-kursi sekolah yang tidak memadai dan ketidakahlian dosen filsafat menjelaskan pada bagian mana filsafat memperkaya theologia. Dengan demikian, dewasa ini sudah menjadi hal yang umun di sekolah-sekolah theologia mahasiswa fobia dengan filsafat. Bertolak dari studi filsafat yang memang rumit untuk dipahami dan kurangnya sumber daya di bidang ini semakin membuat mahasiswa tidak menyukai studi filsafat.

\section{Tidak mampu mendialogkan filsafat dengan teologia}

Pada umumnya, jika diruntutkan pada tokoh-tokoh sejarah filsafat seperti pada era skolastika abad pertengahan. Dapat dilihat pada kebanyakan tokoh, kesalahannya terdapat pada kesenjangan mendialogkan fungsi filsafat di dalam teologia. Beberapa tokoh hanya memberi penekanan lebih pada satu sisi, sementara sisi yang lain diabaikan.

\section{Bersifat intelektual}

Dapat dikatakan bahwa pemikiran filsafat adalah petualangan intelektual (vernunftig), sebab dibentuk oleh aktivitas pemahaman intelektual (Vernunft). Dengan demikian, apa yang bisa dipahami adalah nyata, dan apa yang nyata itu bisa dipahami (vernunftig). ${ }^{16}$ Tipikal filsafat yang intelektual seringkali melupakan intervensi Allah dalam keberadaan dunia, dan sebaliknya mengutamakan keunggulan intelek manusia dalam segala sistem

\footnotetext{
${ }^{14}$ Koentjaraningrat, Metode Penelitian Masyarakat, (Jakarta: Gramedia, 1979), 44

15 Andreas B. Subagya, Pengantar Riset Kuantitatif \& Kualitatif, (Bandung: Yayasan Kalam Hidup, 2004), 153

${ }^{16}$ Simon Petrus L. Tjahjadi, Petulangan Intelektual (Jakarta: Kanisius, 2004), 320
} 


\section{Bersifat abstrak}

Kendati filsafat bersifat abstrak, filsafat dapat membantu dalam kehidupan seharihari. Tentu saja penekanan "hikmat" sebagai pencarian filosofis oleh orang-orang zaman dahulu adalah tepat. Upaya untuk mencari kejelasan arti konsep-konsep dasar tidak akan ada gunanya bila tidak membantu hidup sehari-hari atau tidak mempunyai kontribusi bagai pencapai kebijaksanaan yang telah dibicarakan. ${ }^{17}$ Sifat filsafat yang bersifat abstrak seringkali menjadi pembahasan yang kurang menarik karena memisahkan bagian-bagian dari keseluruhan yang konkrit menjadi ide-ide.

\section{Ketidakahlian pengajar studi filsafat}

Ketidaksukaan mahasiswa dengan studi filsafat teridentifikasi bukan hanya karena faktor intern dari mahasiswa sendiri. Pengajar yang kurang berkompeten memaparkan seluruh kenyataan, rumusan dan kontroversi filsafat dengan theologia juga merupakan faktor pendorong sikap mahasiswa tidak menyukai studi filsafat.

\section{Hubungan Filsafat Dengan Teologia}

Untuk menyelesaikan persoalan yang sudah penulis paparkan di atas, maka sebaiknya kita perlu memahami hubungan antara filsfat dan teologi, pada hakikatnya filsafat memiliki beberapa unsur untuk mengenalnya:

\section{Karakteristik Filsafat}

Untuk menentukan satu karakteristik mendasar dari filsafat tidaklah mudah, karena tiap tokoh mempunyai sudut pandang masing-masing merumuskan karakteristik filsafat. Namun demikian berdasarkan pengertian filsafat menurut Harold $\mathrm{H}$. Titus yang mengatakan:

First, Philosophy is a set of views and the universe, which are often held uncritically. Second, philosophy is process of reflecting on and criticizing our most deeply held conceptions and beliefs. Third, philosophy is rational attempt to look at the world as whole. Fourth, philosophy of the logical analysis of language and the clarification of the of words and concepts. The five, philosophy of group of parennial problems that interst people and for which philosophers always have sought answers. ${ }^{18}$

Sehubungan dengan itu, Joseph Tong mengemukakan karakteristik mendasar dari penelitian filosofis, yakni: "It is general (universal), not particular, global not detailed; it is fundamental, not phenomenal; it is holistic, not partial". ${ }^{19}$ Hal sama diungkapkan oleh Soetrino bahwa karakteristik berfikir filosofis adalah bersifat menyeluruh (komprehensif), mendasar (mendalam) dan spekulatif (menyatu). ${ }^{20}$ Lebih dari itu karakteristik filsafat dikemukakan pada umumnya adalah radikal, universal, konseptual, koheren dan konsisten, sistematis, komprehensif, responsibilitas dan akuntabilitas. ${ }^{21}$ Secara konkrit karakteristik penelitian filosofis dapat diterapkan seperti delapan poin seperti yang dikemukakan oleh Norman L. Geisler dan Paul D. Feinberg, yang menjelaskan demikian:

\footnotetext{
${ }^{17}$ Norman L. Geisler \& Paul D. Feinberg, Filsafat..., 20

${ }^{18}$ Harold H. Titus, Marilyn S. Smith, Living Issues In Philosophy, (California: Wadsworth Company, 1986), 7-9

${ }^{19}$ Joseph Tong, Fondation of Philosophical Theology, (Los Angeles: ITS, 1996), 3

${ }^{20}$ Soetrino, Filsafat Ilmu Metodologia Penelitian, (Yogyakarta: ANDI, 2007), 21

${ }^{21}$ Jan Hendrik Rapar, Pengantar Filsafat..., 21
} 
First, philosophical disputes are not by a lack of factual information. Second, philosophical problem are seldom solved by an appeal to facts. Third, philosophys is often more concerned with method than with theoretical content. Fourth, one of philosophy's chief goals is clarification. The five, philosophy is concerned with the critical reflection. Sixth, philosophical inquiry centers on aquest for truth about crucial issues that are perennially discussed by thoughtful men. Seventh, philosophical analysis and explanation involves appeals to systems of principles. Eighth, some philosophy is concerned with the nature of "being" or "reality". Philosophy studies not only how we know (epistemology) but what we know about reality (metaphysics). ${ }^{22}$

Jadi, karakteristik filosofis tersebut menegaskan mengenai isu-isu pokok yang didiskusikan oleh manusia yang berpikir, karenanya filsafat pasti membuat orang berpikir, sekalipun tidak semua orang yang berpikir adalah filsuf.

\section{Tugas Filsafat}

Pada dasarnya tugas filsafat dapat dikategorikan dalam dua kategori yakni, tugas filsafat secara umum dan secara khusus. Secara umum, filsafat berguna secara teoritis dan praktis, bahwa dengan belajar filsafat orang akan bertambah pengetahuannya, karena filsafat adalah ilmu pengetahuan (philosophy is a science); dengan belajar filsafat orang bertambah kritis dan semakin kreatif berpikir, karena filsafat adalah pola pikir (philosophy as pattern of thingking); dengan belajar filsafat orang akan bertambah bijak dalam hidup, karena filsafat adalah prinsip hidup (philosophy as principles of life) ${ }^{23}$

Secara khusus dalam hubungan dengan theologia, tugas filsafat dikategorikan oleh Joseph Tong dalam tiga kategori, yakni: tugas analitis dan kritis, tugas konstruktif dan tugas produktif. Analitical and critical task (tugas analitis dan kritik), yakni menganalis dan menguji sistem kepercayaan yang umum, dengan maksud untuk mengungkapkan sistem kepercayaan yang palsu. ${ }^{24}$ Tugas filsafat di sini adalah untuk mendefenisikan istilah-isitilah filosofis dan ilmiah, di mana ide-ide yang terkandung di dalamnya dijelaskan. ${ }^{25}$ Constructive Task (tugas konstruktif), yaitu suatu tugas membangun kebenaran sebagai satu kesatuan yang menyediakan wadah berpikir yang maju berkembang. Sedangkan Productive Task (tugas menghasilkan) adalah tugas untuk menambah kejelasan (cimplicity) atau membuat jelas (coherency) dan meneguhkan universalitas kebenaran yang dipegang (universality). ${ }^{26}$ Jadi filsafat bertugas untuk mendalami berbagai pertanyaan asasi manusia tentang makna realitas dan lingkup tanggung jawabnya.

\section{Hakikat Teologia}

Pada hakikatnya theologia merupakan ilmu tentang Tuhan dan hubunganhubungannya dengan alam semesta yang di dalamnya termuat seluruh ajaran Kristen, dan bukan hanya sekedar ajaran tentang Tuhan saja, tetapi juga semua ajaran yang membahas hubungan yang dipelihara oleh Tuhan dengan alam semesta ini. Teologi dan filsafat keduanya berusaha untuk memperoleh pandangan dunia dan pandangan hidup

\footnotetext{
${ }^{22}$ Norman L. Geisler, Paul D. Feinberg, Introduction to Philosophy: A Cristian Perspective, (Grand Rapids: Baker Book House, 1980), 17-20

${ }^{23}$ Stevri Lumintang, Keunikan Theologia ..., 197

${ }^{24}$ Joseph Tong, Fondation Philosophy..., 4

${ }^{25}$ Norman L. Geisler \& Paul D. Feinberg, Filsafat Iman ..., 12

${ }^{26}$ Joseph Tong, Fondation of ..., 4
} 
yang komprehensif. Namun theologia bertolak dari keyakinan akan adanya Tuhan dan la merupakan sumber segala sesuatu, kecuali dosa. ${ }^{27} \mathrm{~J}$. Erickson menyimpulkan intisari theologia dengan mengatakan:

Teologia adalah bidang studi yang berusaha untuk menyampaikan suatu yang berhubungan secara logis tentang doktrin-doktrin iman Kristen, yang terutama berdasarkan Alkitab, ditempatkan pada konteks kebudayaan pada umumnya, dikalimatkan dalam bahasa masa kini, dan berhubungan dengan masalah-masalah kehidupan. ${ }^{28}$

Melalui pernyataan tersebut nampaklah bahwa theologia secara mendasar bersinggungan dengan keselurahan eksistensi kehidupan manusia. Sementara itu, Lumintang mengategorikan hakikat theologia pada beberapa unsur yakni:

Pertama, Iman. Ini merupakan titik berangkat atau dasar mengerti Alkitab. Tanpa iman yang meyakini bahwa Alkitab adalah kebenaran final dari Allah, tidak mungkin memahami kebenaran Alkitab tersebut. Kedua, Allah sebagai subjek dan manusia sebagai objek. Objek studi theologia bukanlah Allah, sehingga Allah dijadikan sejauh ilmu pengetahuan, seperti “ilmu tentang Allah”. Jika Allah menjadi objek penelitian theologis maka akan berujung pada liberal karena Allah diletakkan sebagai objek yang diteliti. Dengan demikian Alkitablah yang menjadi objek studi theologia di dalam iman. ${ }^{29}$

Sehubungan dengan pernyataan Lumintang tersebut, J. Erickson juga membagi hakikat theologia dalam beberapa unsur yakni:

Pertama, Alkitabiah. Dasar utama theologia adalah kitab-kitab kanonik yaitu Perjanjian Lama dan Perjanjian Baru. Kedua, Sistematis. Theologia menggunakan kebenaran dari seluruh Alkitab. Bidang studi ini tidak mengambil ayat Alkitab seenaknya untuk dipisahkan dan disendirikan dari ayat-ayat lainnya, melainkan berusaha untuk menghubungkan berbagai bagian Alkitab menjadi satu keutuhan yang selaras atau logis. Ketiga, kontemporer. Sekalipun ia membicarakan masalah-masalah yang bersifat abadi, theologia harus melakukannya dengan memakai bahasa, konsep serta istilah dan ungkapan yang dapat diterima pada konteks masa kini. ${ }^{30}$

Dari beberapa pernyataan tersebut dapat disimpulkan bahwa hakikat theologia adalah mendasar atas seluruh realita kehidupan manusia bersamaan dengan hubungannya dengan Sang Pencipta dan relasinya dengan alam ciptaan-Nya.

\section{Korelasi Filsafat Dengan Teologia}

Dari semua bidang studi yang berhubungan dengan penyelidikan pengetahuan yang dilakukan oleh manusia, mungkin sekali bidang studi yang paling banyak berinteraksi dengan theologia selama tahun-tahun sejarah gereja adalah filsafat. ${ }^{31}$ Hubungan filsafat Yunani dengan theologia Kristiani merupakan hal yang telah lama menjadi kepentingan Gereja. Setelah ilmu pengetahuan modern dan teknologi menjadi kontroversial. Sementara filsafat mengingatkan akan de-humanisasi, dan agama-agama baru mengungkapkan kerinduan akan Yang Transenden, tumbuhlah juga kesadaran akan kehidupan begitu luas, sehingga diperlukan hubungan kerja sama antar

\footnotetext{
${ }^{27}$ Hendry C. Thiessen, Theologia Sistematika, (Surabaya: Gandum Mas, 2015), 2-4

${ }^{28}$ Millard J. Erickson, Teologi Kristen..., 22

${ }^{29}$ Stevri Indra Lumintang, Keunikan Theologia..., 32

${ }^{30}$ Millard J. Erickson, Theologi Kristen ..., 23

${ }^{31}$ Ibid., 45
} 
pengetahuan lebih dari pada kontroversi. Tidak ada lagi pengetahuan termasuk theologia yang mengaku (claim) diri paling benar. ${ }^{32}$

Secara teknis, filsafat dan theologia selalu membahas masalah-masalah penting yang berkaitan dengan sifat serta tujuan eksistensi manusia, setidak-tidaknya dalam hubungan dengan etika. Dalam arti kata tertentu baik filsafat dan theologia berusaha untuk memberikan suatu pendekatan yang cenderung berintegrasi satu pengertian tentang hidup. ${ }^{3}$ Filsafat dan theologi secara bersaman mengatasi pengetahuanpengetahuan harian ${ }^{34}$, karena masing-masing dengan caranya sendiri bersifat objektif, kritis, metodis, sitematis dan koheren. 35

Hubungan timbal-balik filsafat dan teologia adalah seperti akal dan wahyu, keduanya tidak bertentangan kalau masing-masing hakikatnya dimengerti dengan tepat. Akal budi manusia pada hakikatnya hanya mendemonstrasikan kebenaran sejauh kebenaran itu berkaitan dengan dunia ciptaan ini. Sementara itu, kebenaran yang berasal dari pewahyuan ilahi yang diterima melalui iman sifatnya melampaui kebenaran yang berasal dari akal budi manusia. ${ }^{36}$ Dengan demikian, teologia dan filsafat merupakan satu paket yang tidak dapat dipisahkan dan theologia tidak akan pernah bisa berdiri sendiri.

\section{Kedudukan Filsafat Dengan Teologia}

Teolog Kristen, tentu mengakui bahwa filsafat adalah induk semua ilmu pengetahuan, namun filsafat itu sendiri adalah ancilla theologiae. Sehubungan dengan itu Joseph Tong menuliskan:

Theology originaly is the Master of Philosophy which has been unfortunately treated as specific area of philosophy and science of particular nature dealing with the divine. Its basic concern is cosmic reality (ultimate rality). Out of this concern spings all consequential concern in world all life view. Functioning as a science, theology subject itself to philosophical scrutiny. ${ }^{37}$

Dengan demikian, semua disiplin ilmu, baik theologia, filsafat maupun science harus dikembalikan pada posisi atau letak yang semestinya, bahwa science berada di bawah filsafat, dan keduanya berada di bawah theologia. Jadi, semua ilmu pengetahuan, baik filsafat maupun science adalah ancilla theologiae. Pernyataan ini ditopang oleh epistemologi Kristen yang menegaskan bahwa pengetahuan thelogia berada pada tingkat yang paling tinggi dalam berpikir rasional: common knowledge, sceintific knowledge, emperical knowledge, philosophical knowledge, dan theological knowledge. ${ }^{38}$ Dengan demikian filsafat melayani pemahaman dan penghayatan iman. 39

\footnotetext{
${ }^{32}$ A. Sudiarja, Filsafat dan ...,90

${ }^{33}$ Millard J. Erickson, Theologia Sistematika..., 50

34 Pengetahuan-pengetahuan harian yang dimaksud adalah pengetahuan yang memiliki ciri-ciri seperti: kebetulan, subyektif (pengetahuan didapat hanya faktor simpati dan antipati atau sesuai selera), dan kurang bertalian (kurang memiliki kaitan satu sama lain). Nico Syukur, Pengantar Theologia ..., 20

${ }^{35}$ Ibid., 24

${ }^{36}$ Kalvin S. Budiman, "Mengubah Air Filsafat Menjadi Anggur Theologia”, Jurnal Veritas, Vol. 11, No. 1, April 2010, 176

${ }^{37}$ Joseph Tong, Fundamental Apologetics..., 7

${ }^{38}$ Stevri Indra Lumintang, Diktat Teori Berpikir Logis-Theologis, (Batu: Program Pascasarjana, 2007), 6-8

${ }^{39}$ A. Sudiarja, Filsafat dan Theologia, (Malng: Gandum Mas, 2002), 90
} 
Sekalipun theologia adalah king of philosophy and philosophy is the mother of sciences, ${ }^{40}$ namun arena theologia pun terbatas hanya pada Alkitab sebagai penyataan khusus Allah. Sedangkan arena filsafat dalam batasan penyataan umum Allah, yakni semua ciptaan Allah termasuk dirinya sebagai manusia. Theologia tidak terbatas pada semua filsafat dan ilmu pengetahuan, kecuali pada Alkitab. Itu berarti, theolog tidak memiliki alasan untuk menolak filsafat dan ilmu pengetahuan apapun, selagi itu dipahami sebagai buah dari pemikiran manusia terhadap penyataan umum. Itupun berarti, theolog haruslah filsuf dan ilmuwan. ${ }^{41}$ Sedangkan keterbatasan filsafat dan ilmu pengetahuan terbatas pada penyataan umum, artinya hanya bisa dengan bebas memikirkan dan meneliti kebenaran dari dan tentang dunia serta manusia. Kendatipun manusia dan dunia yang ada di dalamnya secara bebas dipikirkan dan diteliti oleh filsuf dan ilmuwan, namun bagaimanapun pasti ada misteri dari seluruh ciptaan yang tidak mungkin tersingkap seluruhnya. ${ }^{42}$ Kedudukan filsafat sebagai abdi pada theologia akan menunjukkan betapa indahnya jika filsafat memperkaya theologia, khusunya theologia Kristen.

\section{Filsafat Sebagai Ancilia Theologiae}

Istilah ancilla theologiae muncul bermula dari perjumpaan filsafat dengan theologia. Diawali dengan pengalaman Paulus berkhotbah di Atena (Kis. 17:16-34) merupakan emblem perjumpaan theologia dan filsafat. Momen itulah awal rincian episode elaborasi filsafat sebagai ancilla theologiae (hamba theologia) yang merupakan terminologi yang dikatakan oleh para Bapa Gereja, dan menjadi terkenal dalam filsafatnya Thomas Aquinas. Para patristik pada umumnya seperti: Ambrosius, Agustinus, Origenes, Basilius Agung, Gregorius Nisa, Yohanes Krisostomus, dan para Bapa Gereja yang lain mengadopsi dan mengintegrasikan filsafat ke dalam theologia. Sebagai ancilla theologiae mereka memandang bahwa filsafat sangat berperan dalam refleksi iman Kristiani. 43

Sebaliknya Iman Kristiani mempengaruhi diskursus (pemikiran) filsafat, mentransformasikannya sebagai ancilla theologiae, filsafat adalah hamba yang bertugas memudahkan manusia memahami secara rasional aneka misteri iman yang diwahyukan Allah karena wahyu sering kali "tidak masuk akal". ${ }^{44}$ Agustinus berpendapat bahwa theologia dapat diuraikan dengan jelas oleh filsafat. Agustinus menekankan pentingnya iman serta penerimaan wahyu Alkitab, namun juga mengatakan bahwa filsafat dapat membantu untuk memahami theologia Kristen lebih baik. ${ }^{45}$ Contoh paling jelas adalah apa yang disebut sebagai "Inkarnasi". Inkarnasi jelas bertentangan dengan apa yang disebut prinsip Actus Purus ${ }^{46}$ kodrat Allah. Filsafat membantu theologi sedemikian rupa

\footnotetext{
${ }^{40}$ Lumintang mengatakan theology is the king of philosophy and philosophy is the mother of sciences dalam artian bahwa theologia merupakan tuan dari filsafat atau filsafat merupakan pelayan bagi theologia, dan filsafat merupakan induk dari segala ilmu pengetahuan. Dengan demikian theologia mendapat supremasinya. Stevri Indra Lumintang, Keunikan Theologia,... 205

${ }^{41}$ Stevri Indra Lumintang, Keunikan Theologia, ... 205

${ }^{42}$ Soetrino, Filsafat Ilmu, ... 23

${ }^{43}$ Armada Riyatno, Filsafat Devinitas (Keilahian) "Theologi”, Jurnal Veritas, (Vol. 04, No. 01, Mei 2015) 57

44 Ibid., 60

${ }^{45}$ Millard J. Erickson, Theologia Kristen..., 57

${ }^{46}$ In scholastic philosophy, actus purus (literally "pure act") is the absolute perfection of God. Created beings have potentiality that is not actuality, imperfections as well as perfection. Only God is simultaneously all that He can be, infinitely real and infinitely perfect: 'I am who I am' (Exodus 3:14). His attributes or His operations,
} 
bahwa misteri iman yang tidak bisa dipahami oleh budi manusia sepenuhnya itu tidak berarti irrasional. 47

Istilah filsafat sebagai Ancilla Theologiae terus diproklamirkan Thomas Aquinas dalam kefilsafatannya. Ia adalah filsuf Kristen berkebangsaan Italia, lahir pada tahun 1255 dan meninggal tahun $1274 .{ }^{48}$ Istilah Ancilla Theologiae dipakai saat beliau menggunakan filsafat dalam bertheologia, karena baginya philosophy is acilla theologiae (handmaiden of theology). Baginya kebenaran filsafat yang benar tidak bertentangan dengan iman Kristen, adapun alasan yang dikemukakannya adalah sebagai berikut: First, philosophy can prove by means of reason unaided by reveletion some truths proposed by christian faith. Second, it can clarify truths which cannot be proved. Third, it can defend the principles of Cristian faith against their detractors. 49

Pengertian filasat memperkaya theologia dalam kerangka ancilla theologiae, bahwa filsafat bukan sekedar alat, melainkan membantu dalam pengertian memperkaya, yaitu menambah jelas, pasti dan kuat mengenai sistem berpikir theologis (pemahaman, pegangan dan penyajian) theolog mengenai teks dalam konteks dan konteks terhadap teks yang diformulasi dan dipresentasikan. ${ }^{50}$ Memahami hal tersebut, pada hakikatnya filsafat tidak musuh bagi theologia.

\section{Filsafat mengintegrasikan rasio, iman dan wahyu}

Wahyu atau penyataan adalah penyingkapan secara adikodrati oleh Allah mengenai kebenaran yang tidak mungkin diketahui oleh kekuatan rasio manusia tanpa dibantu. Rasio atau nalar adalah kemampuan alami dari pikiran manusia untuk mengetahui kebenaran. Sedangkan iman dalam kerangka filosofis adalah suatu sistem kepercayaan. ${ }^{51}$ Seorang filsuf periode awal skolastik yang bernama Johanes Scotus Eriugena (810-870) dari Irlandia adalah filsuf yang mendasari filsafatnya berdasarkan pemikiran Kristiani. Oleh karena itu segala penelitiannya dimulai dari iman, sedangkan wahyu ilahi dipandang sebagai sumber bahan-bahan filsafatnya. Menurutnya, rasio bertugas mengungkapkan arti yang sebenarnya dari bahan-bahan filsafat yang digalinya dari wahyu ilahi itu. ${ }^{52}$ Rasio merupakan instrument filsafat. Dengan demikian, kegiatan berfilsafat dalam kekristenan akan memperjelas peran dan hubungan rasio dengan iman (faith) dan wahyu (revelation).

\section{Filsafat meyakinkan kebenaran filosofis sebagai kebenaran Allah}

Allah telah memilih untuk menyatakan diri-Nya kepada manusia melalui wahyu umum dan wahyu khusus. Wahyu umum disebut karena penerimanya semua orang dan pokok pemasalahannya theologia secara luas yaitu melalui alam semesta. Wahyu umum datang melalui komunikasi verbal. Wahyu khusus begitu dinamakan karena lebih spesifik atau ketat dalam penerimaannya yaitu hanya melalui Alkitab. Tujuan dari pemberian wahyu ini adalah supaya manusia mengenal kebenaran Allah. ${ }^{53}$

\footnotetext{
are really identical with His essence, and His essence necessitates His existence. Heberman Charles, "Actus Purus" http://acording.philosophy-scholastic.blogspot.co.id. Diakses pada tanggal 19 Agustus 2016

47 Armada Riyatno, Filsafat Devinitas...,71

${ }^{48}$ Colin Brown, Filsafat Iman 1 ..., 28

49 Joseph Tong, Fondation ..., 164

${ }^{50}$ Stevri Indra Lumintang, Keunikan..., 164

${ }^{51}$ Norman L. Geisler \& Paul D. Feinberg, Filsafat Iman ..., 277

${ }^{52}$ Harun Hadiwijono, Sari Filsafat..., 89

${ }^{53}$ W. Gary Crampton, Verbum Dei, (Surabaya: Momentum, 2011), 32
} 
Filsafat tidak dapat memfasilitasi manusia mengenal Allah, namun filsafat yang benar adalah bersumber dari penyataan Allah, sehingga dengan demikian kebenaran filosofis adalah kebenaran Allah. Tentu kebenaran filosofis bukanlah kebenaran yang membawa manusia mengenal Allah dan bukanlah kebenaran yang menyelamatkan, melainkan kebenaran yang menolong manusia untuk hidup bijaksana dan bermoral. ${ }^{54}$ Filsuf Kristen, Arthur F. Holmes, mengajak orang percaya bahwa semua kebenaran di manapun itu ditemukan adalah kebenaran Allah. Karena itu orang Kristen tidak perlu menolak studi akademis yang bersifat filosofis. ${ }^{55}$ Kepercayaan tidaklah timbul sematamata karena dukungan filsafat atau sumber-sumber lainnya, tetapi kepercayaan itu timbul didukung oleh kedua disiplin ilmu ini. Kebenaran yang diajarkan theologia dan kebenaran yang diajarkan filsafat adalah dua kebenaran berbeda yang bersumber dari kebenaran di dalam diri Allah itu sendiri. ${ }^{56}$

Untuk itu filsafat adalah suatu penyelidikan untuk kebenaran, maka filsafat akan memberi kontribusi kepada pengertian kita tentang Allah dan ciptaan-Nya. Lebih jauh lagi, sejarah memperlihatkan bahwa argumen-argumen filosofis dan konsep-konsep telah memperluas dan berperan penting dalam perkembangan theologia Kristen untuk memperkuat argumentasi kebenaran filosofis sebagai kebenaran Allah. ${ }^{57}$

\section{Filsafat Memperkuat Apologetika Kristen}

Selain tugas menjalankan Amanat Agung Yesus Kristus, kekristenan tidak boleh meniadakan tugas yang lain yang juga menanti orang-orang Kristen yang tidak kalah pentingnya, yakni memberi penjelasan tentang iman Kristen, mempertahankan kebenaran Kristen, dan bahkan "menyerang" wawasan dunia yang tidak sesuai dengan kebenaran Kristen..$^{8}$ Filsafat sangat berkaitan erat dengan apologetika, karena tidak mungkin mempelajari apologetika tanpa dibarengi dengan mempelajari filsafat. Apologetika adalah salah satu disiplin ilmu di bidang theologia filosofika (philosophical theology). Filsafat memperkaya theologi Kristen dalam pengertian memperkuat proklamasi (declarative) kebenaran theologis kepada orang yang berbeda latar belakang agama. Dengan pendekatan filosofis, maka orang yang bukan Kristen akan terbuka untuk mendengarkan dan memikirkan presentasi atau proklamasi kebenaran theologia Kristen. 59

Norman L. Geisler dan Paul D. Feinberg juga memberi penjelasan tugas filsafat dalam apologetika Kristen, yakni:

Dalam tugas negatif, pertama: Filsafat menunjukkan serangan-serangan atas Kekristenan adalah tidak benar, maksudnya, berlawanan dengan kenyataan atau kontradiktif. Kedua: menunjukkan bahwa pandangan non Kristen belum tentu benar, maksudnya mungkin benar, tetapi belum tentu. Jelas tidak ada cara untuk secara efektif menyelesaikan tiap tugas ini tanpa menggunakan peralatan filosofis yaitu cara berpikir yang jernih, konsisten dan tepat. Tugas positifnya, memerlukan bukti-bukti yang baik untuk pengesahan kebenaran dasar agama Kristen. Biasanya ini membutuhkan argumen-argumen yang mendukung Allah (Teisme) da bukti-bukti yang

\footnotetext{
${ }^{54}$ Stevri Indra Lumintang, Keunikan Theologia..., 204

${ }^{55}$ Arthur F. Holmes, Segala Kebenaran ..., 2

${ }^{56}$ Millard J. Erickson, Theologia Kristen ..., 47

${ }^{57}$ Kalvin S. Budiman, Mengubah Air..., 176

${ }^{58}$ Fanny Kaseke, Diktat Apologetika Kristen, (Tanjung Enim: STTE, 2016), 1

${ }^{59}$ Stevri Indra Lumintang, Theology The Queen..., 123
} 
mendukung kebenaran sejarah agama Kristen. Tugas ini jauh lebih tepat dipundak filsafat. ${ }^{60}$

Dapat disimpulkan bahwa filsafat memperkaya theologia Kristen, secara khusus di bidang apologetika yakni untuk mempertanggungjawabkan iman Kristen dari oposisi yang menyerang Kekristenan.

\section{Filsafat meneguhkan kepercayaan kristen}

Percaya atau kepercayaan adalah dasar praktik, dan praktik merupakan bukti percaya. Kebanyakan paham ateis mengemukakan bahwa kepercayaan kepada Allah bersifat mengalienasikan (terisolasi). Oleh sebab itu, orang yang beriman harus memperlihatkan bahwa kepercayaan itu bukanlah suatu perbuatan sewenang-wenang, melainkan karena kepastian yang timbul atas kesadaran dan akal manusia. ${ }^{61}$ Salah satu instrumen Kristen yang diserang oleh filsafat adalah infallibility Alkitab. Dalam dua tingkat, filsafat menolak Alkitab sebagai sumber kebenaran mutlak dan sumber faktafakta ilmiah. Filsafat juga menganggap Alkitab fallible (dapat keliru). Filsafat juga menilai bahwa pemberitaan hanya dapat dinilai secara subjektif. ${ }^{62}$

Tetapi di sisi lain theologia kadang-kadang diteguhkan oleh filsafat. Ketika kepercayaan Kristen mulai berjumpa dengan kekafiran dan juga agama-agama non Kristen lainnya, perlulah ditemukan suatu dasar netral untuk mendirikan kebenaran amanat yang berwibawa. ${ }^{63}$ Thomas Aquinas menemukan landasan netral di dalam argumentasi Aristoteles yang mendukung adanya Allah. ${ }^{64}$ Dalam kasus ini theologia memperoleh kredibilitasnya dari filsafat. Bagi sebagian orang pembahasan kepercayaan dianggap sebagai penyelidikan filosofis yang terlalu jelimet tanpa kaitan dengan studi. Dengan demikian kepercayaan itu merupakan kepercayaan asal-asalan. Sehubugan dengan itu filsuf Kristen yang bernama Arthur F. Holmes memberi penjelasan demikian: Menurut saya permasalahan utama yang dihadapi sekarang ialah orang sudah tidak percaya lagi kepada kebenaran. Ini bukan hanya berarti mereka tidak percaya bahwa kekristenan itu benar, tetapi adanya konsep kebenaran itu sendiri yang sudah tidak diakui lagi. Masalah terstimulus oleh: hilangnya fokus kepada kebenaran, hilangnya universilitas kebenaran dan hilangnya kesatuan kebenaran. ${ }^{65}$

Dengan demikian usaha meneguh kepercayaan terhadap kebenaran memerlukan bantuan filsafat. Seperti yang dikatakan oleh filsuf Packer perihal infallibility Alkitab, ia mengatakan:

Philisophy clarify a quality of never deceiving or misleiding. Filsafat memperjelas isi Alkitab sebagai kebenaran, tidak pernah berusaha menipu atau menyesatkan. Infallibility ini berlaku atas seluruh Alkitab berdasarkan jaminan janji-janji-Nya bahwa tidak mungkin Alkitab berdusta (Tit. 1:2; Yoh. 10:35; 17:17; Mat. 5:18) melainkan Alkitab itu benar adanya. ${ }^{66}$

\footnotetext{
${ }^{60}$ Norman L. Geisler dan Paul D. Feinberg, Filsafat Iman ..., 78

${ }^{61}$ Louis Leahy, Aliran-aliran Besar Ateis, (Jakarta: BPK Gunung Mulia, 1990), 13

${ }^{62}$ Dorothy I. Marx, Boleh Aku..., 48

${ }^{63}$ Millard J. Erickson, Theologia Kristen..., 58

${ }^{64}$ Colin Brown, Filsafat Iman 2..., 29

${ }^{65}$ Arthur F. Holmes, Segala Kebenaran..., 18

${ }^{66}$ Dorothy I. Marx, Boleh Aku..., 49
} 
Beberapa tokoh filsafat dan alirannya memang telah keliru memahami Alkitab sebagai kebenaran mutlak. Contohnya, demitologisasi ${ }^{67}$ dari Rudof Bultman dan dengan de-eskatologi dari Albert Schweitzer. ${ }^{68}$ Untuk meneguhkan kepercayaan, mengingat banyak orang yang tidak percaya, maka kebenaran theologis dapat diformulasikan terlebih dahulu dalam kerangka filosofis yang dapat diakui oleh semua orang dalam konteks ruang dan waktu yang berbeda. ${ }^{69}$ Dengan berfilsafat seseorang telah menunjukkan kepecayaan apa yang ia yakini dan mengerti. Seseorang tidak mungkin menjelaskan apa yang tidak jelas pada dirinya. ${ }^{70}$

Pada hakikatnya filsafat bukanlah musuh bagi theologia Kristen. Filsafat pada dasarnya merupakan ilmu yang mencoba memberi kontribusi terhadap kekristenan. Hanya karena ulah segelintir orang yang mencoba mengintegrasikan kedua kubu ini, tanpa pertimbangan-pertimbangan esensialnya, maka timbullah bibit radikalisme yang menitikberatkan hanya pada salah satu pihak. Telah berabad-abad filsafat tampak seperti tombak yang terus mempertajam pisaunya untuk mematikan theologia. Filsafat telah mencapai keemasannya menemukan konsep-konsep yang bertentangan dengan theologia Kristen. Demikian juga sikap gereja pada abad pertengahan yang fanatik terhadap dunia sekuler, telah memperluas kesenjangan filsafat dengan theologia. Alhasil, bukan sedikit orang menjadi liberal dan menyerang keotentikan Alkitab sebagai wahyu Allah.

\section{Penerapan Prinsip Filsafat Sebagai Ancilia Theologiae Bagi Mahasiswa STT}

Dari penyajian di atas penulis mencoba memberikan beberapa prinsip dalam penerapan prinsip Filsafat sebagai ancile teologia bagi mahasiswa STT

\section{Meninjau Ulang Hakikat Filsafat}

Meninjau ulang berarti memikirkan ulang demi proses pencapaian lebih tepat. Pada umumnya orang yang tidak tertarik dengan filsafat adalah orang yang tidak mengerti atau salah mengerti mengenai filsafat. ${ }^{71}$ Memikirkan inti sari atau dasar filsafat, sesungguhnya sistim filsafat telah memberikan sumbangsih dalam mendorong pikiran manusia yang menghasilkan penemuan dan pengertian rahasia alam. Filsafat secara fundamental mewakili usaha manusia yang tidak habis-habisnya mencari kebenaran, dan kekristenan adalah titik akhir dari usaha manusia itu. ${ }^{72}$

\footnotetext{
${ }^{67}$ Demitologisasi menurut Bultman adalah seluruh bahasa PB adalah bersifat mite (simbol). Mite menurutnya merupakan suatu kenyataan, bukan mengenai dunia konkrit-obyektif dengan segala keadaannya, melainkan suatu ekspresi dan cara untuk mengekspresikan persaaan manusia tentang dunia yang didiaminya. Mite menyatakan cara berpikir dan pengungkapan pikiran pada zaman dahulu yang dianggap kuno, terbelakang, kurang sesuai dengan perkembangan ilmu pengetahuan masa kini. Dengan demikian hal-hal yang bersifat mitos (kelahiran Yesus dari Perawan Maria) perlu dibuang karena dianggap sebagai cerita kuno atau hanya cara pengungkapan perasaan manusia pada zaman klasik. Dorothy I. Marx, Boleh Aku ..., 20

${ }^{68}$ Albert Schweitzer mengatakan Injil yang ada sekarang merupakan campuran antara berita eskatologi Yesus dengan konsep-konsep Apokaloptis. Karena itu untuk menemukan Yesus yang historis dan eskatologi yang konsekuen, Injil harus dimurnikan dari unsur-unsur apokaliptis. Gunaryo Sudarmanto, Theologi Kontemporer..., 40.

${ }^{69}$ Stevri Indra Lumintang, Keunikan Theologia..., 216

${ }^{70}$ Millard J. Erickson, Theologia Kristen..., 83

${ }^{71}$ Stevri Indra Lumintang, Theology The..., 94

${ }^{72}$ Colin Brown, Filsafat 1..., i
} 


\section{Menghilangkan Atipati Terhadap Filsafat}

Antipasti sekelompok orang terhadap fisafat tampaknya merupakan suatu tradisi turun temurun. Seperti pada masa munculnya tantangan Marxisme, yang memunculkan theologia-theologia sosial di Eropa dan theologia pembebasan di Amerika Latin. Seruan Nietzche mengenai kematian Tuhan serta filsafat eksistensialisme turut menyumbangkan perasaan antipati terhadap filsafat pada sekelompok orang. ${ }^{73}$

Antipati mahasiswa STT terhadap studi filsafat seringkali muncul dipicu oleh kliseklise filsafat yang terlalu bersifat intelektual dan merupakan hanya karakteristik pemuasan logika manusia. Pada hal semua karakteristik manusia yang menggambarkan ketinggian dan keagungan pada dasarnya merupakan akibat dari akal yang dimilikinya, serta pemanfaatannya untuk kegiatan berpikir. Bahkan Tuhan pun memberikan tugas pengelolaan (yang terbingkai dalam perintah dan larangan) di muka bumi pada manusia tidak terlepas dari kapasitas akal untuk berpikir, berpengetahuan, serta membuat keputusan untuk melakukan atau tidak melakukan tanggungjawab inherennya sebagai manusia, sehingga perlu dimintai pertanggungjawaban. ${ }^{74}$

\section{Belajar Dari Kesalahan Sejarah}

Belajar Belajar dari kesalahan sejarah berarti mengupayakan suatu penyelidikan masa lampau perihal kekeliruan yang sudah pernah terjadi dan telah berlalu. Seseorang tidak mampu memperbaiki kesalahan pada masa lampau tetapi seseorang bisa belajar dari sejarah untuk mencegah supaya tidak mengulangi kesalahan yang sama. Pada tingkat yang lebih canggih, tradisi sikap negatif terhadap filsafat dilanjutkan dengan serangan-serangan terhadap kritik biblika dan theologia dengan alasan bahwa filsafat telah mengambil aturan main theologia dan menggatikan theologia dengan filsafat. ${ }^{75}$ Memiliki sikap fobia terhadap filsafat akan membawa mahasiswa pada sikap pasif. Kepasifan yang demikian, tampaknya amatlah sulit untuk mencoba menyatakan posisi filsafat dalam theologia.

\section{Rekonstruksi Paradigma Yang Salah}

Rekonstruksi terhadap paradigma yang salah dengan filsafat pada bagian ini ingin mengupayakan memberi kerangka berpikir yang benar dengan filsafat, sehingga stigma orang terhadap filsafat dapat diluruskan. Ada beberapa paradigma yang salah dari mahasiswa STT yang perlu direkonstruksi.

\section{Filsafat bukan alat setan}

Konsep-konsep yang saling bertentangan telah sering menimbulkan pertikaian yang tidak terdamaikan, sehingga filsafat dianggap semakin berbahaya dan kacau balau. Mendukung pernyataan tersebut Stevri I. Lumintang memberi pendapat, yakni:

Klimaks penolakan sebagian orang Kristen terhadap filsafat dipresentasikan dengan anggapan bahwa filsafat adalah berbahaya bagi kekristenan, karena filsafat adalah alat setan. Filsafat diidentikkan dengan penyangkalan iman Kristen, alat iblis yang menghancurkan iman orang percaya. Dengan mengutip Kolose 2:8, mereka dengan tegas mewanti-wanti bahkan menakut-nakuti sesamanya supaya tidak ditawan oleh filsafat yang menipu (deceptive philosophy). ${ }^{76}$

\footnotetext{
${ }^{73}$ A. Sudiraja, Theologia dan ..., 101

${ }^{74}$ Obet Nego, Filsafat Ilmu (bahan ajar), (Tanjung Enim: STTE, 2015), 6

75 James Barr, Fundamentalisme, (Jakarta: BPK Gunung Mulia, 1996), 319

${ }^{76}$ Stevri Indra Lumintang, Theology The..., 89
} 
Berdasarkan data yang penulis peroleh di kalangan mahasiswa STT mengenai problematika studi filsafat, diketahui mereka juga menduga bahwa filsafat adalah suatu pemikiran yang terlalu bahaya di dalam theologia Kristen. Mengingat bahwa memang ada sejumlah besar filsuf bersama alirannya menentang sebagian doktrin-doktrin Kristen, maka peristiwa ini menjadi salah satu titik tolak mahasiswa STT mengambil sikap fobia terhadap filsafat dengan mengadopsi istilah Lumintang yang mengatakan alat iblis. Pada hal jika filsafat dipelajari secarah intesif dan berupaya melihat keunggulan yang berperan memperkaya theologia, maka filsafat bukanlah alat setan.

\section{Kekristenan tidak meniadakan filsafat}

Bertitik tolak dari landasan teori pada bab dua, bahwa theologia atau Alkitab tidak meniadakan peran filsafat melainkan Paulus sendiri memainkan peran filsafat saat berkhotbah di Atena (Kis. 17:16-34). 77 Pasca periode rasul-rasul Kristus dan bapa-bapa Gereja, memasuki abad pertengahan bahwa ternyata filsafat telah melahirkan bermacam-macam ilmu. Keunggulan filsafat ini telah membentuk rumusan-rumusan theologis dengan suatu penelitian sistematis terhadap kebenaran-kebenaran Alkitab. Dengan demikian, suatu ketidakmungkinan untuk meniadakan peran filsafat di dalam theologia Kristen.

\section{Filsafat menolong untuk bersikap terbuka dan dinamis}

Elemen kritis dan evaluatif dari filsafat bisa membantu seseorang untuk melepaskan diri dari cengkeraman prasangka, kepicikan dan pemikiran yang dangkal. Kondisi seperti ini cenderung akan menutup sistem berpikir seseorang (close system) terhadap sistem berpikir orang lain. Melalui pemikiran filsafat seseorang dapat menjaga jarak antara keyakinan-keyakinan pribadi sendiri dengan keyakinan orang lain, dan memandang semua itu sedikit skeptif ${ }^{78}$ Sikap menutup sistem pemikiran kerap kali tidak disadari tetapi teraplikasi dalam suatu waktu tertentu. Dampak praktisnya, seseorang sulit bersosialisasi dengan orang-orang sekitarnya. Pada situasi yang lain sikap ini juga muncul dengan cara pendirian yang menganggap prinsip-prinsipnya lebih benar sehingga tidak terbuka (non dinamis) dengan orang asing. Tidak dapat dipungkiri bahwa kecenderungan yang demikian timbul karena banyak faktor, salah satunya adalah faktor ketidaksukaan mahasiwa terhadap studi filsafat dan gejala-gejala inilah yang nampak di kalangan mahasiswa STT.

\section{Mampu melakukan penelitian yang sistematis}

Salah satu tugas utama filsafat dalam suatu penelitian adalah melengkapi ilmuilmu dengan cara membandingkan dan meneliti secara sitematis hasil ilmu-ilmu dengan pengetahuan intuitif mengenai alam raya, pengetahuan yang lebih konkret, sambil mendukung pembentukan skema-skema berpikir yang lebih menyeluruh. ${ }^{79}$

Herbert Spencer memberi definisi filsafat sebagai pengetahuan yang seragam lengkap, berlainan dengan ilmu pengetahuan yang merupakan kesatuan pengetahuan khusus. Maksudnya adalah bahwa filsafat mencoba untuk mempersatukan beberapa ilmu pengetahuan agar menjadi suatu sistem yang seragam, sebagaimana masingmasing pengetahuan khusus mencoba untuk mempersatukan di dalam bidangnya

\footnotetext{
${ }^{77}$ Lihat bab dua halaman 45-46 mengenai perjumpaan theologia dengan filsafat

${ }^{78}$ Norman L. Geisler \& Paul D. Feinberg, Filsafat Dari..., 19

${ }^{79}$ Harry Hamersma, Pintu Masuk..., 48
} 
masing-masing fakta-fakta khusus agar menjadi suatu sistem yang seragam, ini adalah konsepsi yang ambisius dari filsafat. ${ }^{80}$ Sebagai seorang mahasiswa theologia, maka mahasiswa STT Arastamar Bengkulu haruslah memiliki kesukaan yang dalam untuk mempelajari filsafat. Seseorang yang duduk di kursi pendidikan, tentu dituntut berpikir secara ilmiah, terstruktur dan sistematis.

\section{Berpikir secara kritis}

Popper dalam tulisan Hamersma memberi pendapatnya bahwa tugas filsafat adalah berpikir kritis tentang alam raya dan tempat manusia di dalamnya. Kritis yang dimaksud adalah sebagai re-thingking dengan upaya suatu sikap keterbukaan dengan penghargaan dan juga kritis yang dimaksudkan adalah suatu penyelidikan kritis mengenai hasil ilmu-ilmu abstrak demi mencapai suatu gambaran yang lebih menyeluruh. ${ }^{81}$ Sehubungan dengan pernyataan tersebut Erickson dalam bukunya "Teologi Sistematika 1" menuliskan: "ada tiga sumbangan yang diberikan oleh filsafat terhadap theologia, salah satu diantaranya adalah meneliti dengan cermat dan kritis akan semua konsep dan argumentasi theologis". ${ }^{82}$ Ini menyimpulkan bahwa filsafat akan mendorong seseorang untuk berpikir kritis demi mencapai sebuah keabsahan pernyataan theologis.

Menyikapi pada visi STT yaitu mahasiswa harus memiliki kedewasaan spiritual, berwawasan luas dan teologis, berkemampuan prosfesional serta menyadari dan memahami panggilannya sebagai hamba Tuhan. Pencapaian visi ini khusus pada poin berwawasan luas dan berkemampuan profesional sangatlah didominasi dengan pemikiran yang kritis. Berpikir secara kristis mendorong seseorang untuk mengupayakan sesuatu yang lebih baik, dalam hal ini akan meningkatkan kemampuan secara profesional.

\section{Simpulan}

Istilah ancilla theologiae merupakan slogan yang diproklamasikan oleh Thomas Aquinas. Slogan ini memuat suatu konsep berpikir yang mengatakan bahwa filsafat adalah abdi theologia dan secara fungsional merangkumkan suatu tugas filsafat yaitu bahwa filsafat memperkaya theologia. Memahami filsafat sebagai ancilla theologiae merupakan suatu pemahaman yang sangat penting bagi mahasiswa theologia. Mengingat bahwa pada dasarnya keseluruhan ilmu lahir dari pemikiran filsafat termasuk theologia, maka merupakan suatu sikap yang kurang wajar jika seorang theolog fobia terhadap filsafat.

Meskipun ketegangan antara filsafat dan theologia dalam paruhan era sejarah filsafat dan kekristenan telah menorehkan citra yang buruk terhadap filsafat. Namun, hal itu tidaklah menjadi suatu peristiwa sejarah yang dapat melumpuhkan peranan filsafat dalam theologia. Ketegangan antara filsafat dan theologia bukanlah kondisi yang muncul dari fungsinya masing-masing, keadaan tersebut hanyalah karena ulah segelintir orang yang kurang mampu mengintegrasikan kedua kubu tersebut. Jika seandainya para filsuf jujur dan transparan untuk mempropagandakan filsafat dan theologia, maka tidak mungkin ada kesenjangan antara theologia dengan filsafat.

\footnotetext{
${ }^{80}$ Wadjiz Anwar, Nilai Filsafat Dalam Dunia Modern, (Bandung: Alumni, 1979), 23-24

${ }^{81}$ Harry Hamersma, Pintu Masuk..., 49

${ }^{82}$ Millard J. Erickson, Teologi Sistematika..., 37
} 
Hal ini tampaklah bahwa ketegangan antara kedua kubu ini tidak terletak pada esensinya masing-masing, melainkan oleh tindakan sekelompok orang yang tidak mampu memberi keseimbangan pada kedua sistem inilah yang menciptakan ketegangan tersebut. Seperti pada abad pertengahan, tampaklah bahwa theologia dan filsafat mencoba untuk berjalan sendiri-sendiri. Theologia menentang gaya berpikir ilmu modern dan menolok hasil-hasil penemuannya. Sementara filsafat sekurang-kurangnya untuk beberapa waktu mengacu kepada ilmu-ilmu baru dan terpisah dari theologia karena fanatisme gereja.

Pada perkembangannya filsafat telah menjadi acuan jalan mengerti theologia. Demi iman akan Allah yang mewahyukan diri dalam sejarah, khususnya dalam Yesus dan demi sabda Allah yang terungkap dalam Kitab Suci, theologia Kristiani tidak boleh beranjak tanpa peran filsafat yang menyelidiki seluruh kenyataan-kenyataan dalam kekristenan. Dengan memahami filsafat sebagai ancilla theologiae, telah mengembalikan posisi theologia sebagai supremasi tertinggi dari keseluruhan bentuk ilmu. Jika melihat tugas dari filsafat, memang sangatlah jelas bahwa di dalam filsafat tidak akan ditemukan kebenaran yang absolut, karena filsafat didasari praduga orang terhadap realita. Namun di dalam theologia tidaklah demikian, sebab sistem theologia didasari atas dasar adanya Allah. Kendatipun demikian, sejarah perjalanan filsafat dengan theologia telah menunjukkan bahwa filsafat telah berkiprah di banyak sendi theologia demi mempertahankan dan meneguhkan theologia. Filsafat sebagai ancilla theologiae menujukkan bahwa tidak seharusnya mahasiswa theologia fobia terhadap filsafat. 


\section{Daftar Pustaka}

Buku:

Anwar Wadjiz,

1979 Nilai Filsafat Dalam Dunia Modern, Bandung: Alumni

Barr James

1996 Fundamentalisme, Jakarta: BPK Gunung Mulia

Brown Colin,

2008 Filsafat \& Iman Kristen 1, Surabaya: Momentum

Crampton W. Gary,

2011 Verbum Dei, Surabaya: Momentum

Durant Will,

1953 The Pleasures of Philosophy: An Attempt at a Consistent Philosophy of Life, New York: Simon and Schuster

Harold H. Titus., Marilyn S. Smith, 1986 Living Issues In Philosophy, California: Wadsworth Company

Indra Lumintang Stevri, 2007 Diktat Teori Berpikir Logis-Theologis, Batu: Program Pascasarjana

Kaseke Fanny,

2016 Diktat Apologetika Kristen, Tanjung Enim: STTE

Kalvin S. Budiman,

2010 "Mengubah Air Filsafat Menjadi Anggur Theologia”, Jurnal Veritas, Vol. 11, No. 1, April

Koentjaraningrat,

1979 Metode Penelitian Masyarakat, Jakarta: Gramedia

Linneman Eta,

1991 Theologia Kontemporer: Ilmu atau Praduga? Batu: Penerbit Institut Injil Indonesia

Leahy Louis,

1990 Aliran-aliran Besar Ateis, Jakarta: BPK Gunung Mulia

Nazir, Moh.,

1988 Metode Penelitian, Jakarta: Ghalia Indonesia

Norman L. Geisler., Paul D. Feinberg,

1980 Introduction to Philosophy: A Cristian Perspective, Grand Rapids: Baker Book House

Nego Obet,

Soetrino,

2015 Filsafat Ilmu (bahan ajar), Tanjung Enim: STTE

2007 Filsafat Ilmu Metodologia Penelitian, Yogyakarta: ANDI

Petrus L. Tjahjadi Simon, 2004 Petulangan Intelektual Jakarta: Kanisius

Ronald H., Nash, 2001 Iman Dan Akal Budi, Surabaya: Momentum

Riyatno Armada,

2015 Filsafat Devinitas (Keilahian) "Theologi”, Jurnal Veritas, Vol. 04, No. 01, Mei

Subagya, Andreas B., 
2004 Pengantar Riset Kuantitatif \& Kualitatif, Bandung: Yayasan Kalam Hidup Sudiarja A.,

2002 Filsafat dan Theologia, Malng: Gandum Mas

Sudiarja A.,

2002 Filsafat dan Teologi, Malang: SAAT

Syukur Dister Nico,

1985 Filsafat Agama Kristiani, Yogyakarta: Kanisius

Tong Joseph,

1996 Fondation of Philosophical Theology, Los Angeles: ITS

Thiessen Hendry C,

2015 Theologia Sistematika, Surabaya: Gandum Mas

Internet:

2016 http://acording.philosophy-scholastic.blogspot.co.id 